\title{
Research on Shifts in Lactate Dehydrogenase Isozymes in Mouse Tissues during Development*
}

\author{
$\mathrm{By}$ \\ Takehiro Kadowaki**, Mitsutaka Yoshida***, Zensho Inafuku**** \\ and Tutomu Takata**
}

\begin{abstract}
Summary
Lactate dehydrogenase $\uparrow(\mathrm{LDH})$ activity and LDH isozyme in seven tissues of ddn strain mice during development from the embryo to the adult were investigated. The following results were obtained: (1) Comparison of the LDH activities in the various tissues on the 19 th day of gestation and the 7 th day after birth showed that the activities in the kidneys, liver and skeletal muscle increased, while, those in the cerebrum, cerebellum, heart and lungs decreased on the 7 th day after birth. (2) The main isozyme activity on the 7 th day after birth shifted to LDH-4 in the cerebrum and to LDH-3 in the cerebellum and heart. (3) Tissue specific isozyme pattern was seen in the cerebrum on the 56 th day after birth and the isozyme activities were in the following order : LDH-

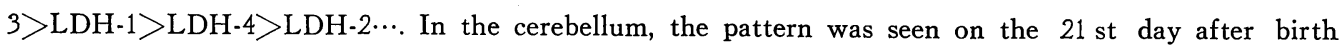
with a gradual decrease of isozyme activity from LDH-1 to LDH-5. In the lungs, the isozyme activities were LDH-5>LDH-4 $\cdots$ from the 12 th day of gestation and even after birth.

Key words: lactate dehydrogenase, ddn strain mouse, LDH isozyme.
\end{abstract}

\section{Introduction}

Lactate dehydrogenase (LDH) is widely distributed in animal's bodies. The tissue LDH isozyme patterns differ between the embryonic period and adulthood. Several authors were interested in the phenomenon of the shift from the embryonic stage to adulthood ${ }^{1,2,3)}$ and investigated the $\mathrm{LDH}$ isozyme patterns in the course of development using mice which have a rapid alteration of generations.
Markert et al.4,5) have already reported on LDH isozymes in tissues during the development of mice. However, the strain name was not recorded, and isozyme patterns during development were not shown for the brain and lungs and there was no differentiation between the cerebrum and cerebellum in the brain.

The authors reexamined the work of Markert et al.5) using mice with clear strain names and made a detailed investigation of the LDH activities and

* マウスの胎児期からの発育段階における各種組織の乳酸脱水素酵素アイソザイムの变動に関する研究.

** 門脇武博, 高田勗, 北里大学医学部衛生学公衆衛生学教室.

*** 吉田光孝, 東邦大学理学部生物学教室.

**** 稲福全昌, 湘央医学技術専門学校.

（受付 1982年 2 月 1 日，受理 1982年5月29日）

$\uparrow$ EC 1.1.1.27 
shifts in their isozyme patterns in seven tissues including the brain and lungs from the embryonic period to adulthood. The results are reported here.

\section{Materials and Methods}

The mouse strain used was specific pathogen free ddn mice (Kitasato Institute). The first day of gestation was set as the day on which the vaginal plug was discovered, and the gestation period was studied at three stages, i. e., the 12 th, 14 th and 19 th days of gestation. These embryonic tissues were prepared as the same tissues from several animals at the same stage because of the minute amounts. The various tissues of the mice after birth were examined at four stages, i. e., the 7 th, 21 st, $42 \mathrm{nd}$ and 56 th days, and samples from an individual animal were prepared.

Seven tissues were used in the experiment : the cerebrum, cerebellum, heart, kidneys, skeletal muscle, liver and lungs. In six animals, the $\mathrm{LDH}$ activity and isozyme patterns were investigated at seven stages from the embryonic stage until adulthood.

Nine-volumes of veronal buffer solution for electrophoresis ( $\mathrm{pH} \mathrm{8.4)} \mathrm{were} \mathrm{added} \mathrm{to} \mathrm{the} \mathrm{tissue.} \mathrm{The}$ suspension was cooled and homogenized and then centrifuged at $13,000 \times \mathrm{g}$ for 30 minutes at $4^{\circ} \mathrm{C}$. The supernate was used for $\mathrm{LDH}$ activity and isozyme pattern measurement.

$\mathrm{LDH}$ activity was measured by the ultraviolet absorption method using a modification of the Hill's method.6) $\mathrm{LDH}$ isozyme measurements were performed at $4{ }^{\circ} \mathrm{C}$ and $5.6 \mathrm{~mA} / \mathrm{cm}$ using cooling type high voltage agar-gel electrophoresis according to Yoshida. ${ }^{7)}$ LDH isozyme activity was calculated by multiplying the LDH activity by the fractional ratio.

\section{Results and Discussion}

\section{1. $\mathrm{LDH}$ activity}

Table 1 shows the $\mathrm{LDH}$ activities of each tissue in each stage of development from embryo to adulthood. It is evident that there was a relative increase in the activities in each tissue in the course of development. When activities on the 7 th day after birth were compared with those on the 9th day of gestation, decreases were found in the cerebrum ( 0.68 fold), cerebellum (0.89-fold), heart ( 0.87 -fold) and lungs (0.97-fold) and increases in the kidneys (2.18fold), liver (1.90-fold) and skeletal muscle (1.67fold).

Among various tissues, the liver was the highest in LDH activity, followed by the heart, skeletal muscle, kidneys, cerebrum, lungs and cerebellum, on the 19 th day of gestation.

The time at which the activity reached a peak after birth differed for each tissue. In the liver, it was on the 7 th day, in the kidneys on the 21 st day and in the other tissues on the $42 \mathrm{nd}$ day. The activity on the 56 th day was highest in the kidneys followed by that of the skeletal muscle, heart, liver, cerebrum, cerebellum and lungs.

The phenomenon of parturition has a major in vivo effect on metabolic regulation and it is considered that metabolic regulation appears when the body is maintained in a homeostatic state by meta-

Table 1. Total activity at embryonic stage (gestational days) and after birth (days after birth) of various tissues of ddn strain mouse.

\begin{tabular}{lrrrrrrrr}
\hline & & Cerebrum & $\begin{array}{c}\text { Cerebel- } \\
\text { lum }\end{array}$ & Heart & Kidneys & Liver & $\begin{array}{l}\text { Skeletal } \\
\text { Muscle }\end{array}$ & Lungs \\
\hline \multirow{3}{*}{ Gestational days } & 12 & 4400 & 3100 & 4500 & 1700 & 5400 & 1600 & $\ldots \ldots$ \\
& 14 & 5200 & 3800 & 10100 & 3200 & 10200 & 3900 & 3000 \\
& 19 & 6500 & 5300 & 16300 & 7300 & 17000 & 7500 & 6100 \\
\hline \multirow{3}{*}{ A.fter birth } & 7 & 4400 & 4700 & 14200 & 15900 & 32300 & 12500 & 5900 \\
& 21 & 8600 & 7900 & 25900 & 25800 & 18500 & 21300 & 6400 \\
& 42 & 12900 & 11900 & 26100 & 24700 & 15800 & 31500 & 6600 \\
& 56 & 8300 & 7300 & 18900 & 23200 & 12900 & 22100 & 4600 \\
\hline
\end{tabular}

Values are units of Hill's modifiéd method per $0.01 \mathrm{ml}$ of supernate. 
bolic changes so that the tissue can adapt to the environment ${ }^{8}$. It is assumed that changes in $\mathrm{LDH}$ activities before and after birth occur as a result of metabolic regulation. However, since the day of peak activity showed tissue difference, interaction of complex intrinsic factors for each of the tissues must be taken into account.

2. $\mathrm{LDH}$ isozyme in each tissue.

1) $\mathrm{LDH}$ isozyme in the cerebrum.

Fig. 1 shows the LDH isozyme pattern in the cerebrum during development from the embryo to adulthood. LDH-5 activity reached a peak in the embryonic cerebrum on the 12 th day of gestation. On the 19 th day of gestation, the main activity shifted to LDH-4, and on the 42 nd day after birth, there were increased LDH-1 and LDH-4 activities and the main activity shifted to LDH-3.

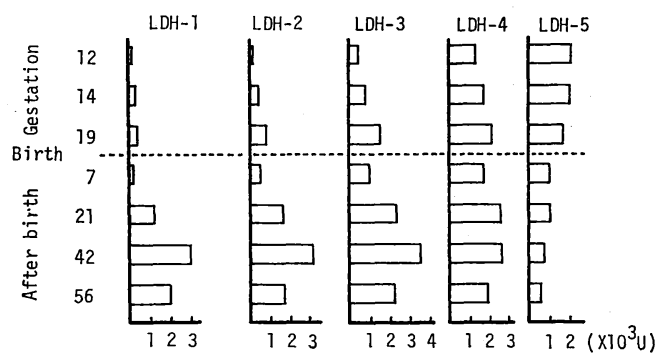

Fig. 1. Histogram of $\mathrm{LDH}$ isozyme patterns during the course of development in the CEREBRUM of the mouse. The numbers along the abscissa indicate LDH activity. The numbers along the ordinate indicate days of gestation or after birth.

Overall changes of the activity was 0.24 -fold in LDH-5, 20-fold in LDH-1, 17-fold in LDH-2 and 5.5fold in LDH-3.

The isozyme activity in the embryonic cerebrum was in the order, LDH-5>LDH-4>LDH-3......, but that in adulthood was in the order, LDH-3>LDH-1 $>\mathrm{LDH}-4>\mathrm{LDH}-2 \cdots \cdots$.

2) $\mathrm{LDH}$ isozymes in the cerebellum.

Fig. 2 shows the results. In the embryonic cerebellum on the 12 th day of gestation, the LDH-5 activity was highest, and on the 19 th day of gestation, the main activity shifted to LDH-4. On the

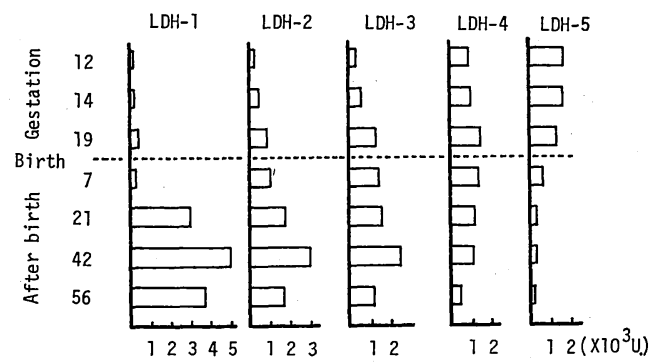

Fig. 2. Histogram of $\mathrm{LDH}$ isozyme patterns during the course of development in the CEREBELUM of the mouse. The numbers along the abscissa indicate LDH activity. The numbers along the ordinate indicate days of gestation or after birth.

7 th day after birth, there were increases in LDH-4 and LDH-3 and on the 21 st day, the main activity shifted to LDH-1.

There was a relative decrease $(0.13$-fold $)$ in the LDH- 5 activity in the course of development, but increases were seen in the activities of LDH-1 (31fold), LDH-2 (8.5-fold) and LDH-3 (4-fold). The isozyme activity in the embryonic cerebellum was in the order, LDH-5>LDH-4>LDH-3....., while the order was LDH-1>LDH-2>LDH-3 in adulthood.

The isozyme patterns in the embryonic cerebrum and cerebellum were similar, but these patterns tended to differ with development after birth. In the cerebrum after birth, the main activity tended to shift gradually in the anodal direction throughout development, while, in the cerebellum, the main activity shifted rapidly from LDH-4 on the 7 th day to LDH-1 on the 21 st day after birth. Therefore, it is suggested from the $\mathrm{LDH}$ isozyme pattern that more aerobic conditions are maintained in the cerebellum than in the cerebrum.

The results of Markert et al.5) concerning LDH isozymes in the brain showed that the main activities were those of LDH-1 and LDH-2. The combined pattern of activities in the cerebrum and cerebellum obtained by the present experiment agreed well with those of Markert et al.5) Flexner et al.9) found the M-type pattern in the cerebral cortex of newborn mice, but in adult mice, the H-type pattern 
was seen. During hypoxia, histopathological changes in the brain occured in the cerebral medulla of immature rats, but the damage was more likely to occur in the cerebral cortex in adult animals ${ }^{10}$. Since the cerebrum used in the present studies was a mixture of the medulla and cortex, it appears that the intermediate type, i. e., LDH-3>LDH-1> LDH-4>LDH-2, was observed.

3) $\mathrm{LDH}$ isozyme in the heart.

Fig. 3 shows the results. The peak of LDH-5 activity in the embryonic heart was seen on the 14 th day of gestation. As the embryo developed, LDH-4 activity increased on the 19 th day of gestation, and the main activity then shifted to LDH-3 on the 7 th day and to LDH-2 on the 21 st day after birth.

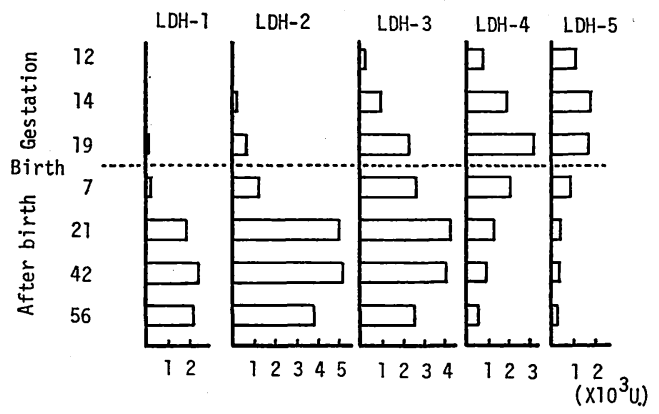

Fig. 3. Histogram of $\mathrm{LDH}$ isozyme patterns during the course of development in the HEART of the mouse. The numbers along the abscissa indicate $\mathrm{LDH}$ activity. The numbers along the ordinate indicate days of gestation or after birth.

Although the LDH-5 activity decreased with development after birth ( 0.22 -fold), there were increases for LDH-1 and -2 (70-fold) and LDH-3 (10.2-fold). Increases in LDH-1 and LDH-2 were remarkable. The order of isozyme activity in the embryonic heart was LDH-5> LDH-4....., while, that in the adult heart was LDH-2 $>$ LDH-3 $>$ LDH $-1 \cdots \cdots$.

4) LDH isozyme in the kidneys.

Fig. 4 shows the results. LDH-5 activity was the highest in the embryonic kidneys, but the activity rapidly shifted with dev elopment so that the

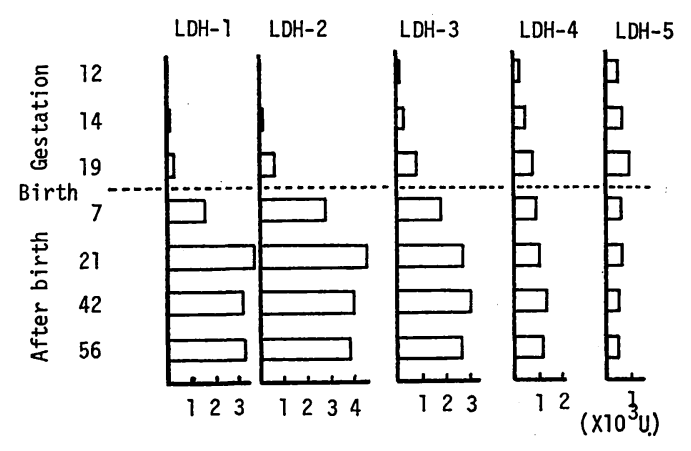

Fig. 4. Histogram of $\mathrm{LDH}$ isozyme patterns during the course of development in the KIDNEYS of the mouse. The numbers along the abscissa indicate $\mathrm{LDH}$ activity. The numbers along the ordinate indicate days of gestation or after birth.

LDH-2 activity became highest on the 7 th day after birth. This main LDH-2 activity did not change even at the end of the experiment.

The LDH-5 activity did not show significant change with development, but there were remarkable increases in the activities of LDH-1 and -2 (78 -fold) and LDH-3 (27-fold).

The order of LDH activity in the embryonic kidneys was $\mathrm{LDH}-5>\mathrm{LDH}-4>\cdots \cdots \cdot$, while, that in adulthood was LDH-2>LDH-1>LDH-3......

In the heart and kidneys, there was a shift in the isozyme activity from LDH-5 to LDH-2 in the course of development, but the courses of the activity shift clearly differed between the two tissues. The results were very similar to those reported by Markert et al.4,5)

With respect to the isozyme activity in the kidneys, Smith et al. ${ }^{11}$ reported that relative amounts of H-type activity reflected the increases in cortical tubules during the course of development. From this, it can be assumed that the course of functional differentiation in accordance with the morphological development of the renal cortical tubules is reflected in the isozyme pattern.

The isozyme activity values in the heart of adult mice were in the order LDH-2>LDH-3>LD $\mathrm{H}-1 \cdots \cdots$, , while, the order was LDH-2>LDH-1 $>$ LD 
$\mathrm{H}-3$ in the kidneys. These tissue specific patterns agreed well with the results of Markert et al.5)

5) $\mathrm{LDH}$ isozymes in the skeletal muscle and liver.

Fig. 5 and 6 show the results. In the isozyme patterns of both tissues, LDH- 5 activity remained predominant during development to adulthood with little change in the isozyme patterns. No LDH-1 activity was detected.

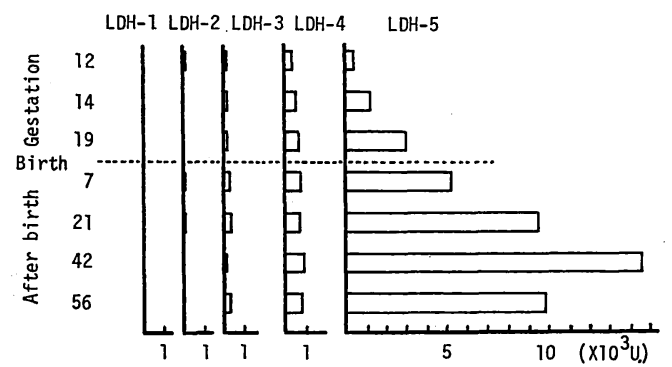

Fig. 5. Histogram of $\mathrm{LDH}$ isozyme patterns during the course of development in the SKELETAL MUSCLE of the mouse. The numbers along the abscissa indicate $\mathrm{LDH}$ activity. The numbers along the ordinate indicate days of gestation or after birth.

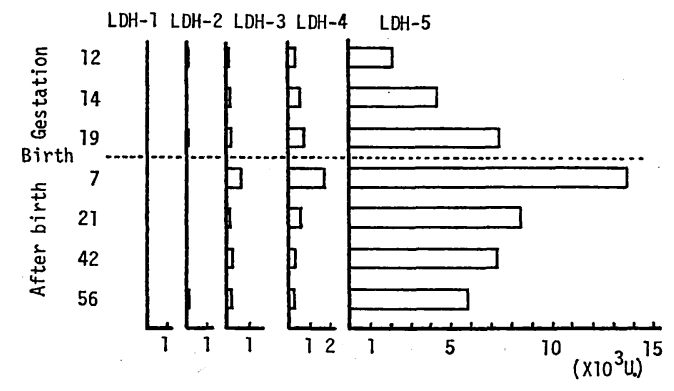

Fig. 6. Histogram of LDH isozyme patterns during the course of development in the LIVER of the mouse. The numbers along the abscissa indicate $\mathrm{LDH}$ activity. The numbers along the ordinate indicate days of gestation or after birth.

The LDH-5 activity in the skeletal muscle showed a gradual increase from the embryonic period until the $42 \mathrm{nd}$ day after birth, while, in the liver, there was a gradual increase from the embryonic period until the 7 th day after birth, followed by a tendency to decrease. The LDH-5 activity in adulthood increased to 28.1-fold and 2.7-fold that in the embryonic period in skeletal muscle and liver, respectively. The isozyme activity in both tissues were in the order LDH-5>LDH-4>….

Shifts in the isozyme pattern in skeletal muscle during development from the embryo to adulthood resembled the results of Markert et al.5) LDH-1 was not detected, but, since LDH is composed of tetramers of $\mathrm{H}$ - and M-type subunits ${ }^{2}$, it appears that LDH-1 was not detected because there were relatively fewer $\mathrm{H}$-type subunits than M-type ones.

6) $\mathrm{LDH}$ isozyme in the lungs.

Fig. 7 shows the results. LDH-5 showed the highest activity during the embryonic period and remained predominant during development to adulthood with little change in the isozyme pattern. The activity increased slightly from the embryonic period until the 7 th day after birth and tended to decrease thereafter. LDH.5 activity in adulthood was less than that in the embryo (0.9-fold), but the activities of LDH-4 and LDH-3 increased 1.4and 8 -fold, respectively. The order of isozyme activity in adult mice was LDH-5>LDH-4>LDH-3> …...

In the results of Markert et al. ${ }^{5)}$, there was a different pattern of LDH-3>LDH-2>LDH-4. Even

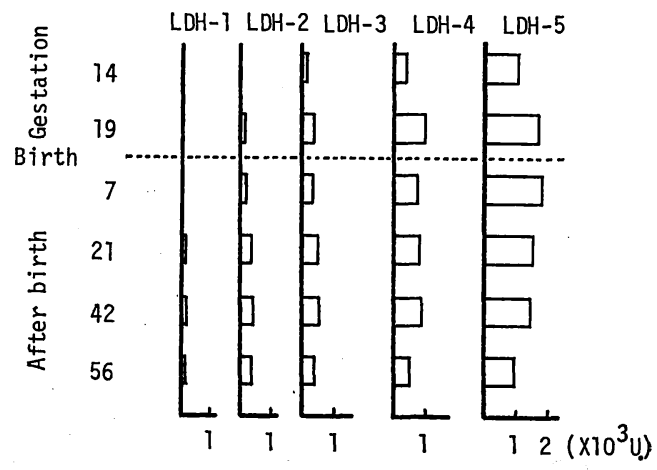

Fig. 7. Histogram of $\mathrm{LDH}$ isozyme patterns during the course of development in the LUNGS of the mouse. The numbers along the abscissa indicate $\mathrm{LDH}$ activity. The numbers along the ordinate indicate days of gestation or after birth. 
though the lungs are in a good condition functionally for the supply of oxygen, the presence of the M-type of isozyme pattern suggests anaerobic conditions. It is not clear whether the difference is due to the effects of intrinsic factors, strain differences or other causes.

The isozyme pattern in the lungs was similar to that in the skeletal muscle, but the activities were very low. From these isozyme patterns, it appears that although the course of functional differentiation is not observed, physiological metabolism is promoted because of the increase in activity.

Fertilized eggs of mice synthesize H-type monomers ${ }^{12)}$, but the supply of oxygen is poor during the process of implantation into the uterus. When M-type monomer synthesis begins to occur, there is a temporary change to M-type pattern and then change back to $\mathrm{H}$-type pattern follows as development progresses ${ }^{13)}$. In the present results, the embryonic tissues showed only M-type pattern. Therefore, it may be that the time of change from $\mathrm{H}$ type to M-type pattern is before the 12 th day of gestation. The intrauterine environment is relatively anaerobic and it is clear from the isozyme patterns of embryonic tissues that the embryo is dependent on anaerobic metabolism to obtain energy. It is also evident that the differences in the isozyme patterns in adult tissues, i. e., tissue specificities, may imply functional metabolic adaptations which are common property of living things. ${ }^{14)}$

The present results can be interpreted on the basis of various factors, e. g., oxygen tension ${ }^{15,16)}$, genes $^{4,5)}$, hormones ${ }^{17)}$, environmental factors ${ }^{15)}$ etc., which have been reported to have close relation to tissue $\mathrm{LDH}$ isozyme patterns.

\section{References}

1) Markert, C.L., and M $\phi 1$ ler, F.: Proc. Natl. Acad. Sci. U.S.A., $45:$ 753-763, 1959.

2) Cahn, R.D., et al. : Science, 136:962-969, 1962.

3) Hinks, M., and Masters, C. : Biochim. Biophys. Acta, $130: 458-468,1966$.

4) Metcoff, J., ed. : Hereditary, Developmental, and Immunological Aspects of Kidney Disease, Northwestern Univ. Press, Evanston, Illinois,
1962, pp. 54-63.

5) Markert, C. L., and Ursprung, H. : Develop. Biol., 5 : 363-380, 1962.

6) Yoshida, M., and Iigima, N. : J. Med. Technol. (Rinshokensa), $15: 1221-1228,1971$.

7) Yoshida, M.: Physico-Chem. Biol. (Seibutsubutsurikagaku), $11: 345-350,1966$.

8) Katsunuma, N., and Ichihara, A., eds. : Metabolic Regulation, Asakura-shoten Press, Tokyo, 1968, pp.119-147.

9) Flexner, L.B., et al. : Develop. Biol., $2: 313$. 328, 1960.

10) Matsuya, T., and Tsukada, U., eds. : Biochemistry of Brain, Asakura-shoten Press, Tokyo, 1969, pp. 75-92.

11) Smith, C.H., and Kissane, J.M. : Develop. Biol., $8:$ : 151-164, 1963.

12) Rapola, J., and Koskimies, O. : Science, 157 : 1311-1312, 1967.

13) Auerbach, S., and Brister, R.L. : Exptl. Cell Res., $46: 89-92,1967$.

14) Suda, M. : Jpn. J. Clin. Med. (Nihonrinsho), $22: 728-731,1964$.

15) Vesell, E.S., et al. : J. Exp. Med., $116: 797$ 806, 1962.

16) Ishida, J., ed. : Developmental Biochemistry, Erimo-shobo Press, Tokyo, 1970, pp.155-171.

17) Dawson, D.M. : Science, 143 : 929-933, 1964.

\section{要 旨}

マウスが胎児期から発育するに伴って，生体内の多 分子型酵素の変動がどのように起っているのかを知る ために, ddn 系マウスを用いて各種組織 LDH アイソ ザイムについて調べた. マゥスの LDH はすでに Markert らによって報告されているが，われわれは新 たに大脳, 小脳, 肺臓を追加し, 胎児期から成熟期に 至る 7 発育段階における詳細な実験を行った.

胎児期の妊娠 19 日目の各組織の LDH 活性值は肝 臓>心臓>骨格筋>腎臓>大脳>肺臓>小脳の順であ り, 成熟期 56 日目では腎臓>骨格筋>心臓>肝臓> 大脳>小脳>肺蔵の順であった。 また, 妊娠 19 日目 と生後 7 日目の各組織の $\mathrm{LDH}$ 活性值を比較すると, 腎臓, 肝藏, 骨格筋の組織では増加するのに対し, 大 脳, 小脑, 心藏, 肝臓の組織では減少がみられた.

妊娠 12 日目の各組織の LDH ア.イソザイムの主分 画はすべて $\mathrm{LDH}_{5}$ であったが，生後 7 日目では大脳 は $\mathrm{LDH}_{4}$ に, 小脳と心臓は $\mathrm{LDH}_{3}$ に, 腎臓は $\mathrm{LDH}_{2}$ に主分画が変動を示した. 成熟期では大脳は生後 56 日目で主分画は $\mathrm{LDH}_{3}$, 小脳は生後21日目で $\mathrm{LDH}_{1}$, 
Vol. 26. No. 5. 1982 (391)

心臓および腎臓は生後21日目で $\mathrm{LDH}_{2}$ を示した。また， 肺臓, 骨格筋, 肝臓では胎児期12日目から成熟期に执い ても $\mathrm{LDH}_{5}$ が主分画であった.
これら LDH アイソザイムの変動はマウスの発育環境 に適応して変動しているのではないかと推定される. 